\title{
Short Communication: Phytochemical diversity and bioactivity of Malaysian Premna cordifolia (Lamiaceae)
}

\author{
DZULSUHAIMI DAUD ${ }^{1,2, \boldsymbol{v}}$, MUHAMMAD SHAFIQ AZAMUDIN MD DEWA ${ }^{2}$, \\ EMI NORZEHAN MOHAMAD MAHBOB ${ }^{1}$, WAN RAZARINAH WAN ABDUL RAZAK ${ }^{2}$ \\ ${ }^{1}$ Faculty of Applied Sciences, Universiti Teknologi MARA. Perak Branch, Tapah Campus, Tapah Road, 35400 Perak, Malaysia. \\ "email: dzuls990@uitm.edu.my \\ ${ }^{2}$ Faculty of Applied Sciences, Universiti Teknologi MARA. 40450 Shah Alam, Selangor, Malaysia
}

Manuscript received: 25 January 2021. Revision accepted: 20 May 2021.

\begin{abstract}
Daud D, Dewa MSAM, Mahbob ENM, Razak WRWA. 2021. Short Communication: Phytochemical diversity and bioactivity of Malaysian Premna cordifolia (Lamiaceae). Biodiversitas 22: 3245-3248. The aims of the present study are to determine the chelation potential and protective effect of Premna cordifolia leaves ethanolic extract in lead intoxicated mice. Twenty-four male mice were divided into four groups with six animals each. Group 1 was healthy mice and received $2 \mathrm{ml} / \mathrm{kg}$ bwt distilled water. Group 2 was healthy mice and supplemented with $200 \mathrm{mg} / \mathrm{kg}$ bwt $P$. cordifolia leaves ethanolic extract. Group 3 was lead intoxicated mice and received 2 $\mathrm{ml} / \mathrm{kg}$ bwt distilled water. Group 4 was lead intoxicated mice and supplemented with $200 \mathrm{mg} / \mathrm{kg}$ bwt $P$. cordifolia leaves ethanolic extract. All treatments were given for 14 days. Chelation activity was determined by measuring the concentrations of lead in the liver, kidney and testis by using atomic absorption spectroscopy. Sperm quality was tested according to World Health Organization manual and testosterone was estimated by using ELISA kit. Spectroscopic data showed that $P$. cordifolia leaves ethanolic extract was able to lower lead concentrations in liver, kidney and testis of lead intoxicated mice. Following a decrease in lead concentrations, sperm quality and testosterone levels were restored in lead intoxicated mice supplemented with $P$. cordifolia leaves ethanolic extract. In conclusion, $P$. cordifolia leaves ethanolic extract has the potential to be developed as an alternative remedy for treating lead poisoning effects.
\end{abstract}

Keywords: chelation activity, lead, phytochemicals, Premna cordifolia, repro-toxicology

\section{INTRODUCTION}

Pollution has many adverse effects on living things. One of the sources of pollution is heavy metals such as lead, one of the most hazardous metals. Lead is widely used in industries such as manufacturing and construction. Therefore, associated industrial workers risk being exposed to lead pollution by inhaling lead-contaminated dust or ingesting lead-contaminated water and food. When exposed to lead, a certain amount will enter the circulatory system and be eliminated through the excretion system. Meanwhile, the rest remains in the body tissues, where lead accumulates over time. Depending on the concentration of lead, it can interfere certain physiological functions. Pneumonitis, bronchitis and metal fume fever are among the diseases experienced by industrial workers exposed to lead poisoning (Sani and Abdullahi 2017). Digestive (vomiting and constipation), bone (osteopenia, osteoporosis and osteomalacia), respiratory (respiratory changes similar to asthma via inducing inflammatory responses), cardiovascular (hypertension, cardiac dysfunction and vascular damage), neurological (cerebellum encephalopathy and edema) and reproductive (miscarriage and sperm count decreases) diseases due to long term lead exposure has been reported by the previous researchers (Flora 2009; Debnath et al. 2019).
Nonserious lead poisoning can be overcome by changing daily lifestyle, including avoiding sources that contain lead. Scientific evidence has also shown that consuming diets rich in iron and calcium may reduce the accumulation of lead in the body. At the moment, the most effective way to treat serious lead poisoning $(45 \mu \mathrm{g}$ of lead in per $\mathrm{dl}$ of blood or higher) is through chelation therapy. Chelation therapy involves administering a chelating agent that will bind to the lead, breaking lead particles down to make them less toxic and facilitating the removal of lead from the body through urine or feces. Although chelation therapy has been proven to be effective in treating lead poisoning, treated patients risk developing side effects such as headache, nausea, vomiting, fever, allergic reactions, abnormal blood pressure and minerals or vitamin deficiencies (Flora and Pachauri 2010). In more serious cases, chelation therapy can also lead to brain, kidney and liver damages as previously reviewed (Daud et al. 2015).

As a result of these side effects, there is growing awareness among researchers to explore new chelating agents with less side effects, including chelating agents from plant sources. Ginkgo biloba, Curcuma longa, Coriandrum sativum, Silybum marianum and Allium sativum are some of the plant species proven effective in treating lead poisoning in animals models (Mehrandish et al. 2019). The present study was conducted to evaluate the phytochemical contents and the potential of Premna 
cordifolia leaves ethanolic extract as a chelation agent. Scientific investigation was also conducted to evaluate the protective effect of $P$. cordifolia leaves ethanolic extract against lead-induced reproductive toxicity in male mice.

\section{MATERIALS AND METHODS}

\section{Chemicals}

All the chemicals and reagents used throughout this study were purchased from commercial sources via local suppliers. Denatured ethanol, diethyl ether and nitric acid were obtained from BDH Chemicals (United Kingdom). Lead acetate, Dulbecco's Modified Eagle Medium (DMEM) and bovine serum albumin were purchased from Sigma Aldrich (USA). Testosterone ELISA Kit was purchased from Cayman Chemical (USA).

\section{Plant materials and ethanolic extract}

Premna cordifolia leaves were collected from their natural habitat in Sekinchan, State of Selangor at the Westcoast of Malaysia during dry and sunny weather. Sample of plant was authenticated by a taxonomist from Universiti Kebangsaan Malaysia. A voucher specimen (UKMB40334) has been deposited at Physiology Research Laboratory, Faculty of Applied Sciences, Universiti Teknologi MARA (UiTM). Initially, the leaves were pulverized into coarse powder and macerated in $80 \%$ ethanol at a ratio of 1:5 (w:v) for seven days at room temperature (Md-Jani et al. 2018). Then the extract was filtered, evaporated using a rotary evaporator (Buchi R210, Switzerland) and lyophilized using a freeze dryer (Christ Alpha 1-4 LD Plus, Germany). The frozen dried extract was stored at $4^{\circ} \mathrm{C}$ until needed and suspended in distilled water prior to usage (Sharkawi et al. 2019).

\section{Phytochemical screening}

The qualitative screening was using standard methods for saponins (Hui et al. 2018), tannins (Harbone 1973), phenol (Sofowora 1993), flavonoids (Hui et al. 2018), alkaloids (Wagner 1993) and steroids (Harbone 1973).

\section{Animals and in-vivo study}

The entire animal experimentation was performed in accordance with the guidelines and authorized by the UiTM Research Committee on Ethical Use in Research (UiTM Care 176/2017). Male mice were purchased from A-Saphire Enterprise (Malaysia). The animals were housed in polyethylene cages under the following conditions; $24 \pm 1$ ${ }^{0} \mathrm{C}, 12$-h light-dark cycle and received mouse pellets and water ad libitum. Following seven days of acclimatization, mice were divided into four groups with six animals each. Group 1 was healthy mice and received $2 \mathrm{ml} / \mathrm{kg}$ bwt distilled water for 14 days. Group 2 was healthy mice and supplemented with $200 \mathrm{mg} / \mathrm{kg}$ bwt $P$. cordifolia leaves ethanolic extract for 14 days. Group 3 was lead intoxicated mice and received $2 \mathrm{ml} / \mathrm{kg}$ bwt distilled water for 14 days. Group 4 was lead intoxicated mice and supplemented with $200 \mathrm{mg} / \mathrm{kg}$ bwt $P$. cordifolia leaves ethanolic extract for 14 days. Healthy mice were maintained with mouse pellets and water ad libitum. Lead-intoxicated mice were maintained with mouse pellet and drinking water containing $1000 \mathrm{ppm}$ lead acetate ad libitum (LotfiGhahramanloo and Baghshani 2016). On day 15, mice were anesthetized with diethyl ether and blood samples $(0.3-0.5 \mathrm{ml})$ were collected by cardiac puncture for testosterone estimation. Then, all animals were sacrificed by cervical dislocation and dissected. Epididymis was collected for sperm quality analysis. Liver, kidney and testis were collected for estimation of lead concentrations.

\section{Estimation of lead concentrations in liver, kidney and testis}

Lead accumulation was estimated using an atomic absorption spectrophotometer (Shimadzu AA670, Japan) as previously described (Daud et al. 2015). Initially, $5 \mathrm{~g}$ of the tissue was homogenized, digested with $10 \mathrm{ml}$ of $65 \%$ nitric acid and heated until the mixture became colorless. Then the mixture was left at room temperature for $30 \mathrm{~min}$, made up to $25 \mathrm{ml}$ by adding deionized water and filtered by using Whatman filter paper No 41. Finally, the amount of lead in the filtrate was estimated at a wavelength of $217 \mathrm{~nm}$.

\section{Sperm analysis}

The cauda epididymis was blotted free of blood and placed in a pre-warmed petri dish containing $1 \mathrm{ml}$ of Dulbecco's Modified Eagle's Medium (DMEM) supplemented with $3 \mathrm{mg} / \mathrm{ml}$ bovine serum albumin. Several incisions were made on cauda epididymis by using sharp needle and unwanted tissues were removed. At this point, the sperm suspension was incubated in $\mathrm{CO}_{2}$ incubator $(5 \%$ $\mathrm{CO}_{2}, 37{ }^{0} \mathrm{C}, 30 \mathrm{~min}$ ) to allow sperm to swim-up. Sperm quality analysis was carried out immediately following incubation using the criteria previously described by World Health Organization (WHO 1999). A drop of sperm suspension was loaded on the Makler Chamber (Sefi Medical Instruments, USA) to count the sperm numbers and sperm motility. The number of sperm was counted on a Makler Chamber's strip of 10 squares and this number represents sperm concentration in million per $\mathrm{ml}\left(10^{6}\right.$ sperm $/ \mathrm{ml}$ ). Sperm motility was calculated by randomly selecting 10 squares on a Makler Chamber, and counting the number of motile and non-motile sperm. To determine sperm morphology, a drop of sperm suspension was loaded on glass slide and sperm smear was prepared, followed by Giemsa staining. Sperm morphology was classified into two general classifications, normal sperm and abnormal sperm (head, midpiece and tail abnormalities).

\section{Estimation of blood testosterone levels}

Testosterone levels were estimated using commercially available ELISA kit in accordance with the manufacturer's instruction (Caymen Chemicals, USA).

\section{Statistical analysis}

All data are presented as mean \pm standard error of mean (SEM). The results were analyzed using one-way ANOVA. Differences were considered statistically significant at $\mathrm{p}<0.05$. 


\section{RESULTS AND DISCUSSION}

\section{Phytochemical screening}

Qualitative phytochemical screening on $P$. cordifolia leaves ethanolic extract showed the presence of saponins, tannins, phenolic, flavonoids, alkaloids and steroids (Table 1). The presence of saponins, phenol, flavonoids, and alkaloids makes the leaves of $P$. cordifolia a potential antioxidant. Leaves of Premna genus are reported to be rich in antioxidants (Onuegbu et al. 2019). These natural antioxidants are substances that may protect living cells against free radicals, collectively known as reactive oxygen species (ROS) that are produced during cellular metabolic reactions and when cells are exposed to toxins such as cigarette smoke, heavy metals or even radiation (Maddu 2019). Previous studies have shown that tannins and flavonoids mainly increase the plant's ability to function as a chelating agent (Amoriwicz 2007; Vaclavikova et al. 2008; Henrik-Klemens et al. 2021).

\section{Estimation of lead concentrations in liver, kidney and testes}

Lead accumulation in liver, kidney and testis increased significantly $(\mathrm{p}<0.05)$ in lead-intoxicated mice (experimental G3) (Table 2). When supplemented with $P$. cordifolia leaves ethanolic extract, lead accumulation in liver, kidney and testes of lead-intoxicated mice (experimental G4) decreased significantly $(\mathrm{p}<0.05)$. The current results suggest that $P$. cordifolia leaves ethanolic extract contains some compounds that can be isolated and developed as chelating agents. The efficiency of $P$. cordifolia leaves ethanolic extract was perhaps due to the presence of tannin and flavonoids, a natural substance that might have chelated lead and enhanced its excretion from the body of lead-intoxicated mice. Evidence showed that tannin fractions have strong chelating ability towards heavy metals including lead, cadmium and copper (Kunnambath and Thirumalaisamy 2015). Spectroscopic study confirmed that flavonoids efficiently facilitate excretion of lead from lead-intoxicated mice and improve reactive oxygen species (ROS) scavenging activity (Adhikari et al. 2018). In addition to, phenol, saponins and alkaloids have also shown potential as heavy metal chelators (Moradkhani et al. 2012; El-Aziza and Khalifab 2018).

\section{Sperm quality and estimation of testosterone levels}

The results show that lead negatively impacts sperm quality (sperm count, sperm motility and sperm morphology) and testosterone secretion, as demonstrated by experimental G3 (Table 3). Lead-intoxicated mice supplemented with $P$. cordifolia leaves ethanolic extract (experimental G4) showed an increase $(\mathrm{p}<0.05)$ in sperm count, sperm motility, sperm with normal morphology and testosterone levels compared to lead-intoxicated mice supplemented with distilled water only (experimental G3). More interestingly, healthy mice supplemented with $P$. cordifolia leaves ethanolic extract (experimental G2) showed a significant $(\mathrm{p}<0.05)$ increment in sperm quality and testosterone secretion.

It is well known that lead poisoning causes oxidative stress in the testes, decreased function of testicular oxidizing enzymes and alters the hypothalamic-pituitary axis (Leon and Pacheco 2020). This effect directly leads to a decrease in sperm quality and testosterone secretion as indicated by the results of this study. The antioxidants contained in $P$. cordifolia leaves ethanolic extract are believed to facilitate the removal of lead from the leadintoxicated mice and restore the functions of the testes in producing sperm and testosterone. A previous study mentioned that antioxidant compounds ameliorate testicular toxicity induced by lead in male animal models via modulating oxidative stress (Soleimanzadeh et al. 2019; El-Khadragy et al. 2020). All these studies showed that sperm production and testosterone levels increased in leadintoxicated animals after being treated with compounds or plant extracts rich with antioxidants.

Table 1. Phytochemical contents of $P$. cordifolia leaves ethanolic extract (PCEE)

\begin{tabular}{llc}
\hline \multicolumn{1}{c}{ Phytochemical } & \multicolumn{1}{c}{ Method } & PCEE \\
\hline Saponins & Froth test & + \\
Tannins & Lead acetate test & ++ \\
Phenol & Ferric chloride test & +++ \\
Flavonoids & Alkaline reagent test & ++ \\
Alkaloids & Wagner's test & ++ \\
Steroids & Salkowski's test & ++ \\
\hline Indicator: +++ strong & present, ++ moderate & presence, + low \\
presence, - absent & &
\end{tabular}

Table 2. The effect of $P$. cordifolia leaves ethanolic extract (PCEE) on lead concentrations in liver, kidney and testis of lead-intoxicated mice. Data are presented as mean $\pm \operatorname{SEM}(\mathrm{n}=6)$.

\begin{tabular}{cccc}
\hline Experimental group & Liver $(\mathbf{u g} / \mathbf{g})$ & Kidney $(\mathbf{u g} / \mathbf{g})$ & Testis (ug/g) \\
\hline G1 & $0.0052 \pm 0.0004^{\mathrm{a}}$ & $0.0067 \pm 0.0001^{\mathrm{a}}$ & $0.0029 \pm 0.0002^{\mathrm{a}}$ \\
G2 & $0.0041 \pm 0.0006^{\mathrm{a}}$ & $0.0058 \pm 0.0003^{\mathrm{a}}$ & $0.0021 \pm 0.0001^{\mathrm{a}}$ \\
G3 & $0.261 \pm 0.08^{\mathrm{b}}$ & $0.293 \pm 0.07^{\mathrm{b}}$ & $0.158 \pm 0.06^{\mathrm{b}}$ \\
G4 & $0.163 \pm 0.05^{\mathrm{c}}$ & $0.202 \pm 0.04^{\mathrm{c}}$ & $0.084 \pm 0.01^{\mathrm{c}}$ \\
\hline
\end{tabular}

Note: G1: Healthy mice supplemented with $2 \mathrm{ml} / \mathrm{kg} \mathrm{dH} 2 \mathrm{O}, \mathrm{G} 2$ : Healthy mice supplemented with 200 mg/kg PCEE, G3: Lead-

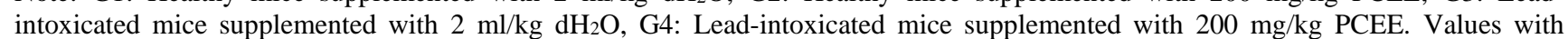
different superscript within the same column show a significant difference at $\mathrm{p}<0.05$. 
Table 3. The effect of $P$. cordifolia leaves ethanolic extract (PCEE) on sperm quality and testosterone levels in lead-intoxicated mice. Data are presented as mean \pm SEM $(n=6)$.

\begin{tabular}{ccccc}
\hline Experimental group & Sperm count $\left(\mathbf{1 0}^{\mathbf{6}} \mathbf{s p e r m} / \mathbf{m l}\right)$ & Sperm motility $(\%)$ & Normal sperm $(\%)$ & Testosterone $(\mathbf{\% g} / \mathbf{m l})$ \\
\hline G1 & $34 \pm 1.8^{\mathrm{a}}$ & $87 \pm 9.4^{\mathrm{a}}$ & $69 \pm 4.8^{\mathrm{a}}$ & $2.1 \pm 0.3^{\mathrm{a}}$ \\
G2 & $53 \pm 2.3^{\mathrm{b}}$ & $97 \pm 6.3^{\mathrm{a}}$ & $83 \pm 5.2^{\mathrm{b}}$ & $2.7 \pm 0.5^{\mathrm{b}}$ \\
G3 & $16 \pm 1.9^{\mathrm{c}}$ & $34 \pm 5.7^{\mathrm{b}}$ & $47 \pm 2.6^{\mathrm{c}}$ & $0.9 \pm 0.1^{\mathrm{c}}$ \\
G4 & $27 \pm 4.3^{\mathrm{d}}$ & $69 \pm 3.4^{\mathrm{c}}$ & $60 \pm 4.3^{\mathrm{a}}$ & $1.8 \pm 0.6^{\mathrm{d}}$ \\
\hline
\end{tabular}

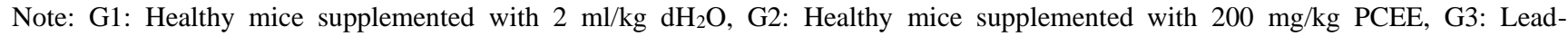

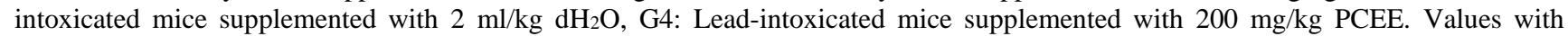
different superscript within the same column show a significant difference at $\mathrm{p}<0.05$.

In conclusion, $P$. cordifolia leaves ethanolic extract supplementation attenuated lead accumulation and reproductive toxicity in lead-intoxicated mice. Current data suggest that $P$. cordifolia leaves ethanolic extract could be developed as a natural chelation agent. However, further studies are needed to evaluate the extract pharmacokinetic, clinical dose, isolation and then characterization of bioactive components.

\section{ACKNOWLEDGEMENTS}

All authors would like to acknowledge the financial and facilities support by the Faculty of Applied Sciences, Universiti Teknologi MARA, Malaysia. All authors also would like to extend their gratitude to Research Management Centre (RMC), Universiti Teknologi MARA, Malaysia for administrative support.

\section{REFERENCES}

Adhikari A, Darbar S, Chatterjee T, Das M, Polley N, Bhattacharyya M, Bhattacharyya S, Pal D, Pal SK. 2018. Spectroscopic studies on dual role of natural flavonoids in detoxification of lead poisoning: Bench to bedside trial. ACS Omega 3: 15975-15987. DOI: 10.1021/acsomega.8b02046.

Amoriwicz R. 2007. Tannins: The new natural antioxidants? Eur J Lipid Sci Technol 109: 549-551. DOI: 10.1002/ejlt.200700145.

Daud D, Md Nawi M, Ismail A, Tawang A. 2015. The effects of Eucheuma cottonii on sperm quality and tissue lead level in rats exposed to lead nitrate. Biotechnol An Indian J 11(4): 138-143.

Debnath B, Singh WS, Manna K. 2019. Sources and toxicological effects of lead on human health. Indian J Med Spec 10: 66-71. DOI: 10.4103/INJMS.INJMS_30_18.

El-Aziza MMA, Khalifab MA. 2018. Biochemical reactions for the removal of heavy metals from aqueous solutions. MOJ Biorg Org Chem 2(4): 179-183. DOI: 10.15406/mojboc.2018.02.0078.

El-Khadragy M, Al-Megrin WA, Al-Sadhan NA, Metwally DM, ElHennamy RE, Salem FEH, Kassab RB, Abdel-Moneim AE. 2020. Impact of coenzyme Q10 administration on lead acetate-induced testicular damage in rats. Oxid Med Cell Longev 2020:1-12. DOI:10.1155/2020/4981386.

Flora SJS. 2009. Structural, chemical and biological aspects of antioxidants for strategies against metal and metalloid exposure. Oxid Med Cell Longev 2(4): 191-206. DOI: 10.4161/oxim.2.4.9112.

Flora SJS, Pachauri V. 2010. Chelation in metal intoxication. Int J Environ Res Public Health 7(7): 2745-2788. DOI: 10.3390/ijerph7072745.

Harborne JB. 1973. Phytochemical methods: A guide to modern techniques of plant analysis. Chapman and Hall, London. DOI: 10.1007/978-94-009-5921-7_1.
Henrik-Klemens A, Bengtsson F, Bjordal CG. 2021. Raman spectroscopic investigation of iron-tannin precipitates in waterlogged archaeological oak. Stud Conserv. DOI: 10.1080/00393630.2020.1864895.

Hui CK, Majid NI, Mohd Zainol MK, Mohamad H, Mohd Zin Z. 2018. Preliminary phytochemical screening and effect of hot water extraction conditions on phenolic contents and antioxidant capacities of Morinda citrifolia leaf. Malays Appl Biol 47(4): 13-24.

Kunnambath PM, Thirumalaisamy S. 2015. Characterization and utilization of tannin extract for the selective adsorption of $\mathrm{Ni}$ (II) ions from water. J Chemistry 2015:1-9. DOI: 10.1155/2015/498359.

Leon OLL, Pacheco JMS. 2020. Effects of lead on reproductive health. IntechOpen. DOI:10.5772/intechopen.91992.

Lotfi-Ghahramanloo M, Baghshani H. 2016. Ameliorative effects of caffeic acid on lead accumulation and oxidative stress in lead-exposed mice. Zahedan J Res Med Sci 18(5): e6674. DOI: 10.17795/zjrms6674.

Maddu N. 2019. Diseases related to types of free radicals. IntechOpen DOI: 10.5772/intechopen.82879.

Md Jani MH, Daud D, Sharkawi N, Hashim H, Ismail NH, Salleh A, Hashim N. 2018. The effect of Zingiber zerumbet ethanol extract (ZZREE) on testosterone level and testes histoarchitecture in high fat diet-induced obese rats. Malays Appl Biol 47(5): 181-187.

Mehrandish R, Rahimian A, Shahriary A. 2019. Heavy metals detoxification: A review of herbal compounds for chelation therapy in heavy metals toxicity. J Herbmed Pharmacol 8(2): 69-77. DOI: 10.15171/jhp.2019.12.

Moradkhani S, Ayatollahi AM, Ghanadian M, Moin MR, Razavizadeh M, Shahlaei M. 2012. Phytochemical analysis and metal chelation activity of Achillea tenuifolia Lam. Iran J Pharm Res 11(1): 177-183.

Onuegbu GC, Eze FI, Ayogu PC, Agbo MO, Ezema CG, Ezema BE. 2019. Phytochemical and in vitro antimicrobial properties of Premna hispida (Verbenaceae) Linn. IOSR J Pharm Biol Sci 14(5): 64-74.

Sani A, Abdullahi IL. 2017. Evaluation of some heavy metals concentration in body fluids of metalworkers in Kano metropolis, Nigeria. Toxicol Rep 4: 72-76. DOI: 10.1016/j.toxrep.2017.01.001.

Sharkawi NA, Ismail NH, Md Jani NH, Daud D, Hashim N, Salleh A, Hashim H. 2019. Curative potential of Zingiber zerumbet on paracetamol-induced hepatoxicity. Malays Appl Biol 48(3): 11-17. DOI: $10.5414 / \mathrm{NHX} 01979$.

Sofowora A. 1993. Medicinal plants and traditional medicine in Africa. Spectrum Books, Ibadan.

Soleimanzadeh A, Kian M, Moradi S, Mahmoudi S. 2019. Carob (Ceratonia siliqua L) fruit hydro-alcoholic extract alleviates reproductive toxicity of lead in male mice: Evidence on sperm parameters, sex hormones, oxidative stress biomarkers and expression of Nrf2 and iNOS. Avicenna J Phytomed 10(1): 35-49.

Vaclavikova R, Kondrova E, Ehrlichova DM, Boumendjel A, Kovar J, Stopka P. 2008. The effect of flavonoid derivatives on doxorubicin transport and metabolism. Bioorg Med Chem 16(4): 2034-2042. DOI: 10.1016/j.bmc.2007.10.093.

Wagner H. 1993. Pharmazeutische Biology. Gustav Fisher Vweleg, Germany.

World Health Organization. 1999. WHO Laboratory Manual for The Examination of Human Semen and Sperm Cervical Mucus Interaction. Cambridge University Press, Cambridge. 